\title{
Growth and stable carbon isotope composition of cold-water macroalgae in relation to light and temperature
}

\author{
C. Wiencke ${ }^{1}$, G. Fischer ${ }^{2}$ \\ ${ }^{1}$ Alfred Wegener Institute of Polar and Marine Research, Am Handelshafen 12, D-2850 Bremerhaven, \\ Federal Republic of Germany \\ ${ }^{2}$ Fachbereich Geowissenschaften, Universität Bremen, Bibliothekstraße, D-2800 Bremen, Federal Republic of Germany
}

\begin{abstract}
Growth rates and stable carbon isotope compositions were determined for cultivated polar and cold-temperate macroalgae of both hemispheres. Growth in macrothalli of endemic Antarctic Desmarestiales was light-saturated at lower irradiances compared to Arctic cold-temperate Laminaria species. Moreover, photoinhibition of growth was more strongly expressed in most Antarctic algae. Isotope studies indicated a relationship between irradiance and carbon isotope ratios. Strong ${ }^{13} \mathrm{C}$ enrichments of about 10 to $25 \%$ with increasing photon fluence rate were measured in Desmarestia antarctica, Himantothallus grandifolius, $L$. solidungula and $L$. digitata; lower but continuous enrichments were found in $D$. anceps, Adenocystis utricularis and Acrosiphonia arcta. In contrast, experiments in the temperature range 0 to $25^{\circ} \mathrm{C}$ did not show continuous isotope changes. However, the isotope ratios were also related to growth rates. Primary $\mathrm{CO}_{2}$ availability in seawater combined with carbon uptake and growth rates are the most important factors determining stable carbon isotope ratios in macroalgae. Rapid carbon assimilation due to high light availability causes cell-internal and/or external disequilibria which result in the preferential uptake of the heavier isotope. Results are important for the interpretation of stable carbon isotope data of organic matter in sediments and for food web studies.
\end{abstract}

\section{INTRODUCTION}

Macrothalli of endemic Antarctic Desmarestiales grow between 0 and $5{ }^{\circ} \mathrm{C}$ (Wiencke \& tom Dieck 1989). Sporophytes of the endemic Arctic Laminaria solidungula and of the cold temperate L. digitata require temperatures of 0 to $15^{\circ} \mathrm{C}$ and 0 to $20^{\circ} \mathrm{C}$ for growth, respectively (Bolton \& Lüning 1982, tom Dieck 1989). In contrast to this knowledge on the effect of temperature on growth under light-saturating conditions little is known about the relationship between growth and irradiance (Lüning 1981).

Stable carbon isotopic ratios from marine benthic macroalgae show a wide range from about -5 to $-35 \%$ (Fry \& Sherr 1984). The reasons for the large variability in marine macroalgae, but also in other aquatic plants, e.g. seagrasses or phytoplankton, are not yet clear. The major cause affecting the $\delta^{13} \mathrm{C}$ values in plants is the isotopic discrimination against ${ }^{13} \mathrm{C}$ at the initial carboxylation step during photosynthesis (Park \& Epstein 1960) but other physiological and environ- mental factors must be responsible for the wide ranges observed in aquatic plants (discussed in Fry \& Sherr 1984).

Under isotopic equilibrium, molecular $\mathrm{CO}_{2}$ in seawater is virtually identical to atmospheric $\mathrm{CO}_{2}$ whereas $\mathrm{HCO}_{3}^{-}$is 9 to $7 \%$ heavier than molecular $\mathrm{CO}_{2}$ in the temperature range 0 to $30^{\circ} \mathrm{C}$ (Deuser \& Degens 1967). Thus, differential use of bicarbonate and dissolved $\mathrm{CO}_{2}$ could determine $\delta^{13} \mathrm{C}$ values of aquatic plants (Benedict et al. 1980).

For marine plankton an increase of $\delta^{13} \mathrm{C}$ values with surface water temperatures has been reported (Sackett et al. 1965, Fontugne \& Duplessy 1981), which was attributed to temperature-sensitive enzymatic reactions. However, isotope experiments with purified enzymes failed to prove that ${ }^{13} \mathrm{C}$ discrimination was dependent upon temperature (Christeller et al. 1976, Estep et al. 1978). According to O'Leary (1981) temperature-influenced enzymatic discriminations must be quite small but variations of isotopic composition in microorganisms may result from the change in $\mathrm{CO}_{2}$ 
availability with temperature (see also Rau et al. 1989). All studies carried out so far showed lower fractionations at lower $\mathrm{CO}_{2}$ levels but a relationship to carbon uptake or growth rates has not yet been demonstrated (Degens et al. 1968a, Calder \& Parker 1973, Lazerte 1983). Recently Wefer \& Killingley (1986) and Cooper (1987) reported effects of light intensity on the stable carbon isotope ratios of the benthic alga Halimeda incrassata and the seagrass Posidonia oceanica, respectively. In our opinion the effects of light intensity on the carbon isotope composition of plants have been underestimated up to now.

A clearer view on the influence of external factors on the carbon isotope composition of macroalgae should be obtained by simultaneous determination of growth. Therefore the aim of this study was to analyse growth and carbon isotope composition in relation to light and temperature. As epibionts are known to falsify $d^{13} \mathrm{C}$ values of macrophytes (Thayer et al. 1978) the study was done using unialgal cultures of macroalgae from polar and cold-temperate regions of both hemispheres. Data on the carbon isotope ratios of such macroalgae in relation to light and temperature are not yet available.

\section{MATERIAL AND METHODS}

The investigated species were: the endemic Antarctic Palmaria decipiens (Reinsch) Ricker, Himantothallus grandifolius (A. \& E. S. Gepp) Zinova, Phaeurus antarcticus Skottsberg, Desmarestia anceps Montagne and Desmarestia antarctica Moe \& Silva; the Antarctic-cold temperate species Prasiola crispa subsp. antarctica (Kützing) Knebel f. antarctica, Acrosiphonia arcta (Dillwyn) J. Agardh, Ulothrix implexa (Kützing) Kützing. Adenocystis utricularis (Bory) Skottsberg isolated on King George Island, Antarctica, by Wiencke \& Clayton (Wiencke \& tom Dieck 1990); the cold temperate species Chordaria magellanica Kylin from South Chile isolated by Wiencke \& Clayton (Wiencke \& tom Dieck 1990); the endemic Arctic Laminaria solidungula J. Agardh from Igloolik, Canada (Bolton \& Lüning 1982) and the cold temperate Laminaria digitata, from Helgoland, North Sea, isolated by Lüning (Bolton \& Lüning 1982).

The species were cultivated in 0.4 to 5 I glass beakers in the laboratories of the Alfred Wegener Institute of Polar and Marine Research, Bremerhaven. As culture medium, membrane-filtered (pore size $0.2 \mu \mathrm{m}$ ) enriched North Sea water $(\mathrm{pH}=8.4$, enriched after Provasoli; Stein 1973) was used and changed weekly to avoid nutrient limitation. The cultures were aerated vigorously with membrane-filtered air (pore size $0.2 \mu \mathrm{m})$. The temperatures in the cultivation rooms were $0,5,10,15$ and $20 \pm 1{ }^{\circ} \mathrm{C}$. For lighting Osram L58/
W 19 daylight 5000 de luxe cold light neon tubes were used. The photon fluence rates were adjusted with neutral grey plastic foil by use of a Licor Quantameter LI-185 B equipped with a LI-190 SB Quantum sensor (Biggs et al. 1971). The initial size of the studied Desmarestiales and Laminariales and of Palmaria decipiens was 5 to $8 \mathrm{~cm}$, in all other species a fresh weight of 100 to $300 \mathrm{mg}$ was used as inoculum. Prior to experiments the algae were cultivated for $10 \mathrm{~d}$ under the respective conditions for acclimation. Growth rates were measured in 5 to 10 individual plants or samples by determination of fresh weight. Growth rates were calculated as

$$
\text { Specific growth rate }\left(\% \mathrm{~d}^{-1}\right)=\frac{100 \ln \mathrm{N}_{\mathrm{t}} \mathrm{N}_{0}^{-1}}{\mathrm{t}}
$$

where $N_{0}=$ initial freshweight; $N_{t}=$ freshweight on Day $t_{;}$and $\mathrm{t}=$ time interval.

For determination of isotopic and chemical composition $(\mathrm{C} / \mathrm{N}, \mathrm{H} / \mathrm{C}$ ratios), the algae were rinsed for $3 \mathrm{~min}$ with ice-cold distilled water to remove the culture medium superficially, and subsequently frozen at $-22^{\circ} \mathrm{C}$. Later the algae were vacuum-dried at $30^{\circ} \mathrm{C}$. A small portion of about 1 to $3 \mathrm{mg}$ taken from the main branch or the blade of each specimen was used. Based on duplicates of cultivated plants, the relative precision was between 0.7 and $2.5 \%$ of the mean $\delta^{13} \mathrm{C}$-value. From a few macroalgae collected in Antarctica, different segments of the thalli were analyzed. Based on 5 measurements, Himantothallus grandifolius, for example, had a mean value of $-19.47 \%$ with a standard deviation of $1.11 \%$. Differences in isotope composition between different plants of the same species were similarly small.

Immediately before weighing and measurement, the algae were dried for $2 \mathrm{~h}$ at $105^{\circ} \mathrm{C}$. C/N and $\mathrm{H} / \mathrm{C}$ were determined with an HEREAUS-CHN-Analyzer. The samples were combusted at $950^{\circ} \mathrm{C}$ in the presence of copper oxide, pure oxygen and pure helium as carrier gas. After measuring $\mathrm{CO}_{2}$ and $\mathrm{N}_{2}$ (reduced with $\mathrm{Cu}$ ) in a conductivity cell the pure $\mathrm{CO}_{2}$ gas was trapped from the helium carrier gas at about $-196^{\circ} \mathrm{C}$ and transferred to a FINNIGAN mass spectrometer (MAT 251) for carbon isotope determination. ${ }^{13} \mathrm{C} /{ }^{12} \mathrm{C}$ ratios are expressed in the usual $\delta$-notation and refer to the limestone standard PDB (Craig 1957). The $\delta$-value is defined as

$$
\delta^{13} \mathrm{C} \text { in } \%=\frac{\mathrm{R}_{\text {sample }}-\mathrm{R}_{\text {standard }}}{\mathrm{R}_{\text {standard }}} \times 1000,
$$

where $\mathrm{R}=$ the isotope ratio ${ }^{13} \mathrm{C} /{ }^{12} \mathrm{C}$. Total reproducibility of the $\mathrm{CO}_{2}$ preparation and measuring procedure was better than $0.15 \%$ on the $\delta$-scale. Further information on the basic principles of mass spectrometry is given by Hoefs (1987). 


\section{RESULTS}

In macrothalli of the endemic Desmarestiales Desmarestia anceps, D. antarctica and in Himantothallus grandifolius growth was light-saturated between 15 and $20 \mu \mathrm{mol} \mathrm{m} \mathrm{m}^{-2} \mathrm{~s}^{-1}$ irrespective of the cultivation temperature (Figs. 1 to 6 ).

In old plants growth rates were generally lower, but the general pattern did not change as demonstrated by D. antarctica (Figs. 4 and 6). At photon fluence rates of $\geq 50 \mu \mathrm{mol} \mathrm{m} \mathrm{m}^{-2} \mathrm{~s}^{-1}$ growth rates considerably decreased in D. anceps and $H$. grandifolius (Figs. 1 to 3 ). Similar growth versus light intensity curves were obtained in the Antarctic-cold temperate Adenocystis utricularis and in the Antarctic isolate of the bipolar-cold temperate Acrosiphonia arcta (Figs. 8 and 9).

A considerable change of isotope composition with increasing irradiance was observed for Himantothallus grandifolius (Fig. 1) and Desmarestia antarctica (Fig. 6). In the light intensity range 1 to $50 \mu \mathrm{mol} \mathrm{m}{ }^{-2} \mathrm{~s}^{-1}$ values increased by ca $20 \%$. For $D$. antarctica a significant change in the chemical composition was indicated by increasing $\mathrm{C} / \mathrm{N}$ ratios with increasing irradiance (Table 1). Moreover, H/C ratios decreased from 2.5 to 1.5.

The 2 isotope curves of Desmarestia anceps $\left(0\right.$ and $5^{\circ} \mathrm{C}$ ) showed a similar shape but the ratios are 3 to $5 \%$ more negative at the lower cultivation temperature (Figs. 2 and 3). At irradiances below $4 \mu \mathrm{mol} \mathrm{m}^{-2} \mathrm{~s}^{-1}$ a small ${ }^{12} \mathrm{C}$ enrichment of less than $1 \%$ was observed whereas between 4 and 50 umol m $\mathrm{m}^{-2} \mathrm{~s}^{-1}$ the values increased by 3 to $4 \%$ with increasing irradiance. The isotope curves showed a comparable shape with the growth curve.

Less distinct ${ }^{13} \mathrm{C}$ enrichments with increasing irradiance $(18: 6 \mathrm{~h}$ light:dark [LD] cycles) were observed for the Antarctic-cold temperate Adenocystis utricularis and the bipolar-cold temperate Acrosiphonia arcta (Figs. 8 and 9) which had much lower specific growth rates than the aforementioned endemic Antarctic Desmarestiales. Under 6:18 h LD cycles in A. utricularis no continuous isotope change with increasing light intensity was found (Fig. 7).

In macrothalli of the endemic Arctic Laminaria solidungula cultivated at $0^{\circ} \mathrm{C}$ (Fig. 10) growth was light saturated at a photon fluence rate of $20 \mu \mathrm{mol} \mathrm{m} \mathrm{m}^{-2} \mathrm{~s}^{-1}$. similar to Antarctic species. However, in plants cultivated at 5 and $10^{\circ} \mathrm{C}$ the light saturation point of growth shifted to between 55 and $60 \mu \mathrm{mol} \mathrm{m} \mathrm{m}^{-2} \mathrm{~s}^{-1}$ (Figs. 11 and 12). At 90 to $120 \mu \mathrm{mol} \mathrm{m} \mathrm{m}^{-2} \mathrm{~s}^{-1}$ a slight decrease of growth rates was observed. In $L$. digitata growth was light saturated between ca 55 and $105 \mu \mathrm{mol} \mathrm{m} \mathrm{m}^{-2} \mathrm{~s}^{-1}$ at all studied temperatures (Figs, 13 and 14). No such decrease in growth rates could be demonstrated at the highest light intensity tested.

In Laminaria solidungula the isotope values increased by ca 15 to $20 \%$ at higher irradiances, whereas at low photon fluence rates of about 1 to $4 \mu \mathrm{mol} \mathrm{m}{ }^{-2} \mathrm{~s}^{-1}$ strong ${ }^{12} \mathrm{C}$ enrichments of about 3 to $16 \%$ were recorded (Figs. 10 to 12 ). The range of the isotope values was similar at the cultivation temperatures of 0 and $5^{\circ} \mathrm{C}$; at $10^{\circ} \mathrm{C}$ the isotope changes with light intensity were less pronounced. Although growth at $0^{\circ} \mathrm{C}$ was light saturated at $20 \mu \mathrm{mol} \mathrm{m} \mathrm{m}^{-2} \mathrm{~s}^{-1}$ the isotope values still increased to some degree (Figs. 10 to 12 ). For L. digitata, similar isotope curves and ranges were observed (Figs. 13 and 14). At photon fluence rates $>3 \mu \mathrm{mol} \mathrm{m} \mathrm{m}^{-2} \mathrm{~s}^{-1}$ isotope variations appeared to reflect growth rate changes.

The carbon isotope versus temperature curves for macroalgae cultivated under growth-saturating light intensities (Figs. 15 to 19) indicate that the isotope variations in the temperature range 0 to $25^{\circ} \mathrm{C}$ were relatively small (ca 2 to $7 \%$ ) compared to the lightinduced changes reported above. Nevertheless, a relationship between the isotope ratios and specific growth rates is visible. With increasing growth rates the isotope compositions changed to heavier values (e.g. Figs. 16 to 19). In Palmaria decipiens and Prastola crispa high growth rates were correlated with slightly higher $\mathrm{C} / \mathrm{N}$ ratios indicating a change in chemical composition (Figs. 16 and 17, Table 2).

\section{DISCUSSION}

The results of the growth data presented here and by Fortes \& Lüning (1980) on Laminaria saccharina indicate that the light saturation point of growth in macrothalli of endemic Desmarestiales is located at low (Figs. 1 to 6 ) and in Arctic-cold temperate Laminaria species at comparatively high photon fluence rates (Figs. 10 to 14). The only exception to this rule was found in $L$. solidungula which at $0^{\circ} \mathrm{C}$ showed a low light saturation of growth (Fig. 10), corresponding to measurements on wild macrothalli (Chapman \& Lindley 1980). This shift of the light saturation point of growth to lower photon fluence rates is most probably related to the inhibition of temperature-dependent enzymatic dark reactions in photosynthesis (cf. Lüning 1985).

Photoinhibition of growth under high photon fluence rates is more strongly expressed in Himantothallus grandifolius (Fig. 1) and Desmarestia anceps (Figs. 2 and 3) compared to Laminaria solidungula, L. digitata (Figs. 10 to 14 ) and L. saccharina (Fortes \& Lüning 1980). Moreover, photoinhibition of growth occurs in $H$. grandifolius and $D$. anceps at lower photon fluence rates than in the Laminaria species.

Similar light versus growth patterns were demonstrated for the microthalli of both algal groups (discussed in Wiencke 1988, 1990). Hence, the Antarctic species are adapted not only to the low temperatures 


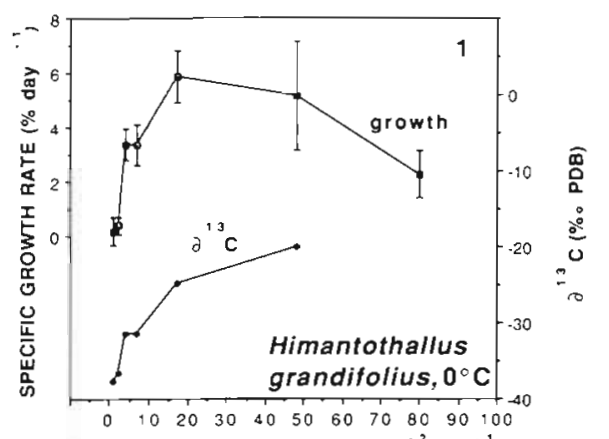

PHOTON FLUENCE RATE $\left(\mu \mathrm{mol} \mathrm{m}^{-2} \mathrm{sec}^{-1}\right)$
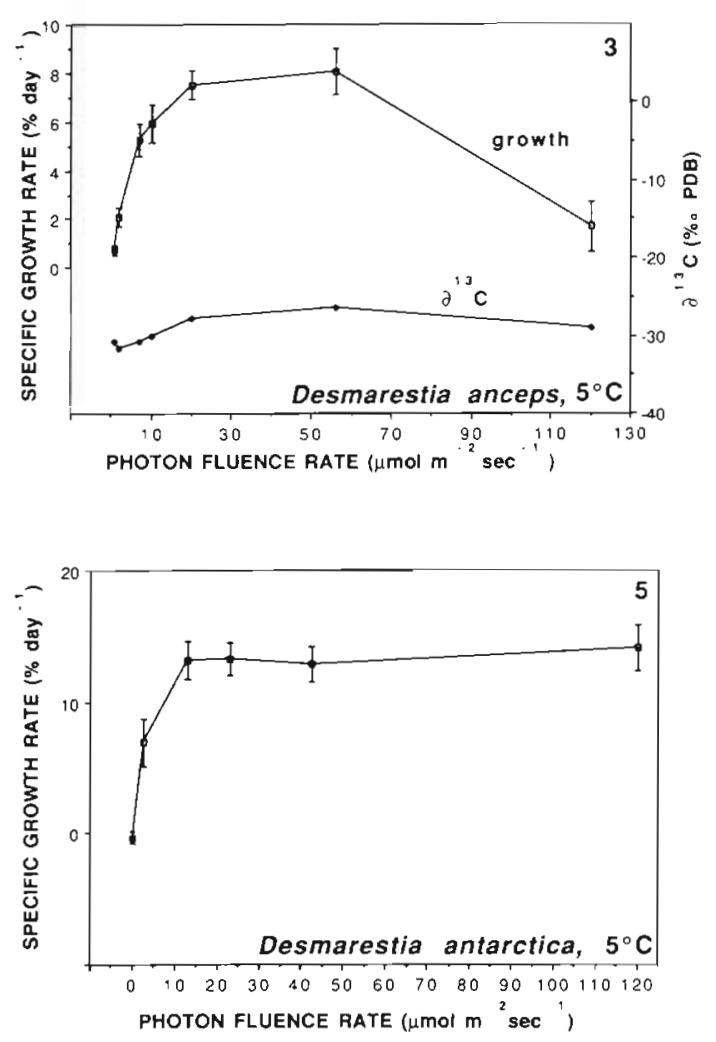

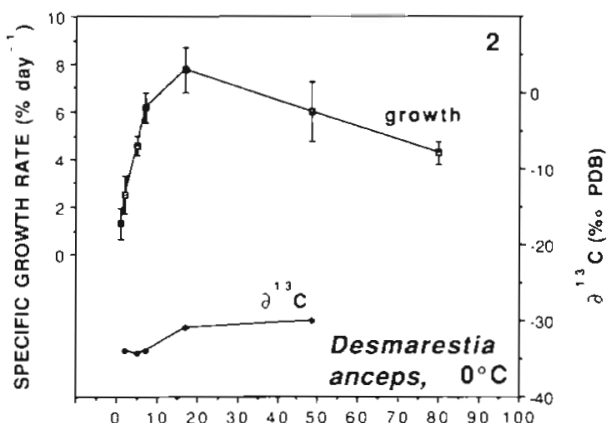

PHOTON FLUENCE RATE ( $\mu \mathrm{mol} \mathrm{m}^{-2} \mathrm{sec}^{-1}$ )
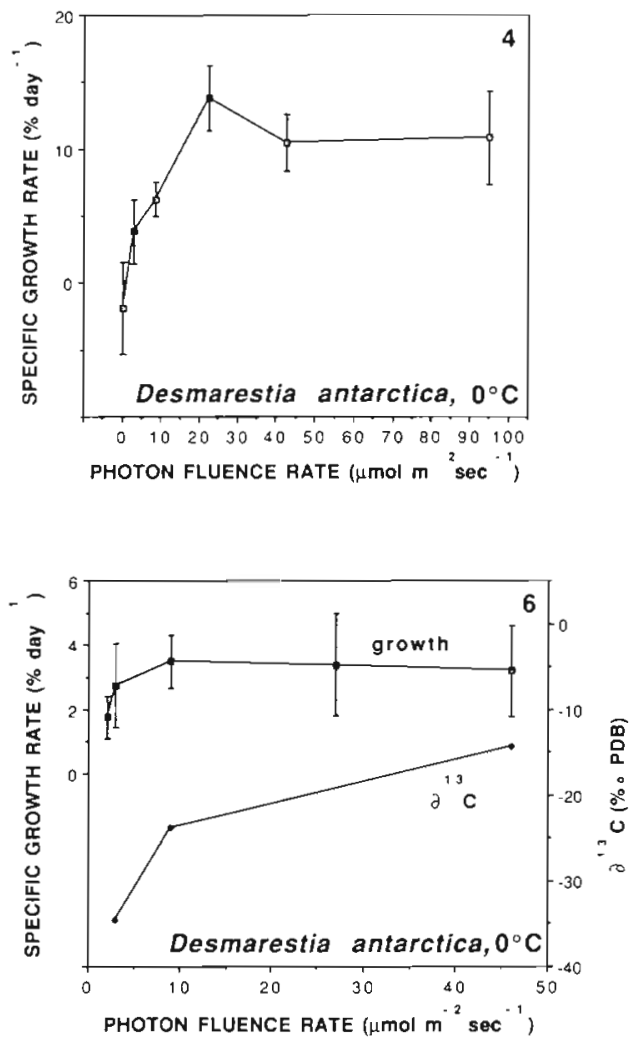
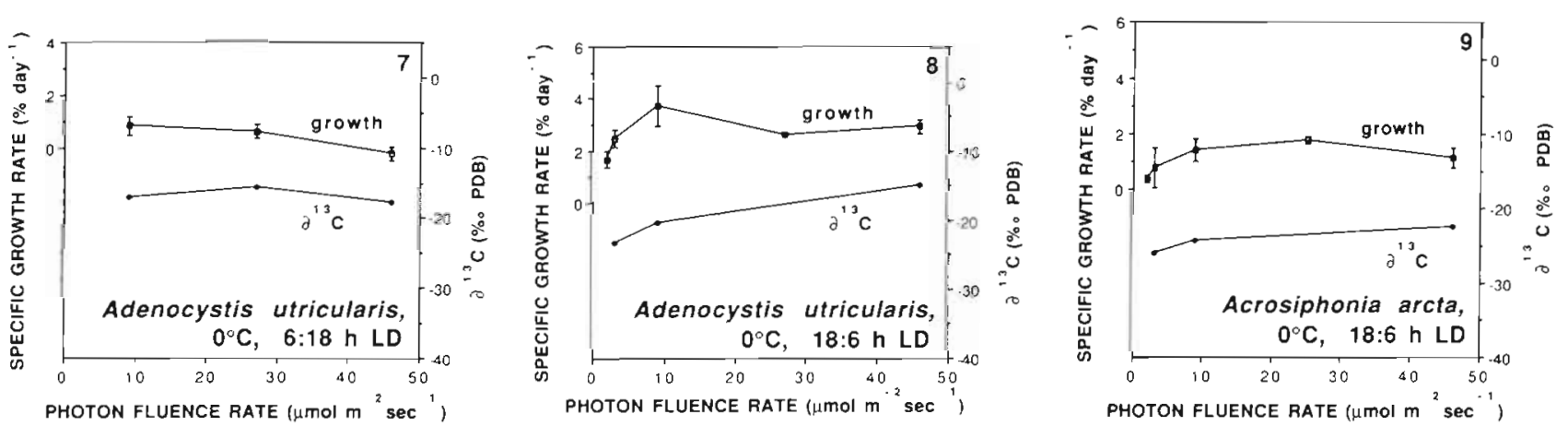

Figs. 1 to 9. Growth and stable carbon isotope composition versus photon fluence rates in endemic Antarctic Desmarestiales (Figs. 1 to 6) and Antarctic-cold temperate species (Figs. 7 to 9). In Desmarestia antarctica either 4 mo old actively growing (Figs. 4 and 5) or 7 mo old plants (Fig. 6) were used. In Adenocystis utricularis the experiments were performed with mature, almost fertile macrothalli exhibiting reduced growth rates. Light:dark (LD) cycles $=18: 6 \mathrm{~h}$ or as indicated 
Table 1. Stable carbon isotope composition and $\mathrm{C} / \mathrm{N}$ values of macroalgae grown under different photon fluence rates

\begin{tabular}{|c|c|c|c|c|c|c|}
\hline Species & $\begin{array}{c}\text { Photon fluence } \\
\text { rate } \\
\left(\mu \mathrm{mol} \mathrm{m} \mathrm{m}^{-2} \mathrm{~s}^{-1}\right)\end{array}$ & $\begin{array}{l}\text { Temp. } \\
\left({ }^{\circ} \mathrm{C}\right)\end{array}$ & $\begin{array}{c}\text { Duration } \\
\text { (wk) }\end{array}$ & $\begin{array}{l}\text { Light:dark } \\
\text { (h) }\end{array}$ & $\begin{array}{c}\delta^{13} \mathrm{C} \\
(\% \text { PDB })\end{array}$ & $\begin{array}{l}\mathrm{C} / \mathrm{N} \\
\text { (atom) }\end{array}$ \\
\hline Himantothallus grandifolius & $\begin{array}{r}1.00 \\
2.50 \\
4.00 \\
7.00 \\
17.00 \\
48.50\end{array}$ & 0 & 5 & $18: 6$ & $\begin{array}{l}-37.64 \\
-36.63 \\
-31.39 \\
-31.40 \\
-24.81 \\
-19.98\end{array}$ & $\begin{array}{l}11.82 \\
15.98 \\
14.04 \\
11.40 \\
12.56 \\
16.22\end{array}$ \\
\hline Desmarestia anceps & $\begin{array}{r}2.25 \\
4.10 \\
7.00 \\
17.00 \\
48.50\end{array}$ & 0 & 5 & $18: 6$ & $\begin{array}{l}-33.95 \\
-34.33 \\
-33.89 \\
-30.82 \\
-29.94\end{array}$ & $\begin{array}{l}13.40 \\
14.01 \\
13.42 \\
13.16 \\
12.67\end{array}$ \\
\hline Desmarestia anceps & $\begin{array}{r}1.00 \\
2.00 \\
7.00 \\
10.00 \\
20.00 \\
56.00 \\
120.00\end{array}$ & 5 & 3.5 & $18: 6$ & $\begin{array}{l}-30.81 \\
-31.70 \\
-30.85 \\
-30.13 \\
-27.87 \\
-26.42 \\
-28.96\end{array}$ & $\begin{array}{l}13.14 \\
13.99 \\
12.34 \\
13.34 \\
14.33 \\
17.11 \\
12.79\end{array}$ \\
\hline Desmarestia antarctica & $\begin{array}{r}3.00 \\
10.00 \\
50.00\end{array}$ & 0 & 5 & $18: 6$ & $\begin{array}{l}-34.66 \\
-23.88 \\
-14.31\end{array}$ & $\begin{array}{l}11.48 \\
23.12 \\
19.11\end{array}$ \\
\hline Adenocystis utricularis & $\begin{array}{r}3.00 \\
10.00 \\
50.00\end{array}$ & 0 & 5 & $6: 18$ & $\begin{array}{l}-17.05 \\
-15.66 \\
-17.68\end{array}$ & $\begin{array}{l}6.56 \\
7.05 \\
8.89\end{array}$ \\
\hline Adenocystis utricularis & $\begin{array}{r}3.00 \\
10.00 \\
50.00\end{array}$ & 0 & 5 & $18: 6$ & $\begin{array}{l}-23.33 \\
-20.47 \\
-15.02\end{array}$ & $\begin{array}{l}11.22 \\
12.95 \\
22.99\end{array}$ \\
\hline Acrosiphonia arcta & $\begin{array}{r}3.00 \\
10.00 \\
50.00\end{array}$ & 0 & 5 & $18: 6$ & $\begin{array}{l}-26.01 \\
-24.27 \\
-22.50\end{array}$ & $\begin{array}{r}10.53 \\
9.24 \\
11.18\end{array}$ \\
\hline Laminaria solidungula & $\begin{array}{r}1.00 \\
2.00 \\
4.10 \\
7.00 \\
17.00 \\
48.50\end{array}$ & 0 & 5 & $18: 6$ & $\begin{array}{l}-23.45 \\
-27.35 \\
-33.13 \\
-28.20 \\
-20.06 \\
-18.74\end{array}$ & $\begin{array}{r}8.55 \\
10.32 \\
8.54 \\
10.32 \\
17.79 \\
12.12\end{array}$ \\
\hline Laminaria solidingula & $\begin{array}{r}1.00 \\
3.00 \\
6.00 \\
10.00 \\
20.00 \\
56.00\end{array}$ & 5 & 5 & $18: 6$ & $\begin{array}{l}-22.76 \\
-38.92 \\
-25.48 \\
-24.16 \\
-22.36 \\
-19.04\end{array}$ & $\begin{array}{l}10.88 \\
10.10 \\
11.89 \\
10.90 \\
17.94 \\
12.59\end{array}$ \\
\hline Laminaria solidungula & $\begin{array}{r}1.00 \\
2.00 \\
5.00 \\
12.00 \\
26.00 \\
59.00\end{array}$ & 10 & 5 & $18: 6$ & $\begin{array}{l}-27.27 \\
-30.70 \\
-29.26 \\
-27.67 \\
-23.45 \\
-18.34\end{array}$ & $\begin{array}{r}6.91 \\
9.96 \\
11.42 \\
12.53 \\
14.69 \\
13.46\end{array}$ \\
\hline Laminaria digitata & $\begin{array}{r}0.00 \\
2.50 \\
4.10 \\
7.00 \\
17.00 \\
48.50\end{array}$ & 0 & 5 & $18: 6$ & $\begin{array}{l}-21.59 \\
-30.20 \\
-29.26 \\
-30.97 \\
-24.47 \\
-29.08\end{array}$ & $\begin{array}{r}10.16 \\
9.93 \\
6.51 \\
10.42 \\
7.52 \\
10.95\end{array}$ \\
\hline
\end{tabular}


(Continued)

\begin{tabular}{|c|c|c|c|c|c|c|}
\hline Species & $\begin{array}{c}\text { Photon fluence } \\
\text { rate } \\
\left(\mu \mathrm{mol} \mathrm{m} \mathrm{m}^{-2} \mathrm{~s}^{-1}\right)\end{array}$ & $\begin{array}{l}\text { Temp. } \\
\left({ }^{\circ} \mathrm{C}\right)\end{array}$ & $\begin{array}{l}\text { Duration } \\
\text { (wk) }\end{array}$ & $\begin{array}{l}\text { Light:dark } \\
\text { (h) }\end{array}$ & $\begin{array}{c}\delta^{13} \mathrm{C} \\
(\% \text { PDB })\end{array}$ & $\begin{array}{l}\mathrm{C} / \mathrm{N} \\
\text { (atom) }\end{array}$ \\
\hline Laminaria digitata & $\begin{array}{r}0.00 \\
3.00 \\
6.00 \\
12.00 \\
20.00 \\
55.00 \\
120.00\end{array}$ & 5 & 6 & $18: 6$ & $\begin{array}{l}-14.70 \\
-34.44 \\
-26.87 \\
-23.25 \\
-17.00 \\
-12.05 \\
-12.10\end{array}$ & $\begin{array}{r}10.71 \\
5.29 \\
6.61 \\
6.16 \\
7.99 \\
7.86 \\
8.38\end{array}$ \\
\hline Laminaria digitata & $\begin{array}{r}0.00 \\
2.00 \\
4.00 \\
12.00 \\
26.00 \\
59.00 \\
107.50\end{array}$ & 10 & 6 & $18: 6$ & $\begin{array}{l}-22.73 \\
-37.52 \\
-30.14 \\
-31.60 \\
-17.83 \\
-17.70 \\
-11.54\end{array}$ & $\begin{array}{r}13.53 \\
8.00 \\
7.56 \\
7.47 \\
11.12 \\
12.72 \\
12.35\end{array}$ \\
\hline
\end{tabular}

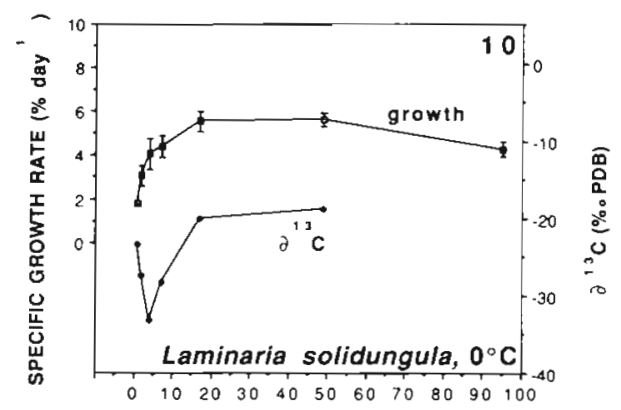

PHOTON FLUENCE RATE ( $\mu \mathrm{mol} \mathrm{m}^{-2} \mathrm{sec}^{-1}$ )
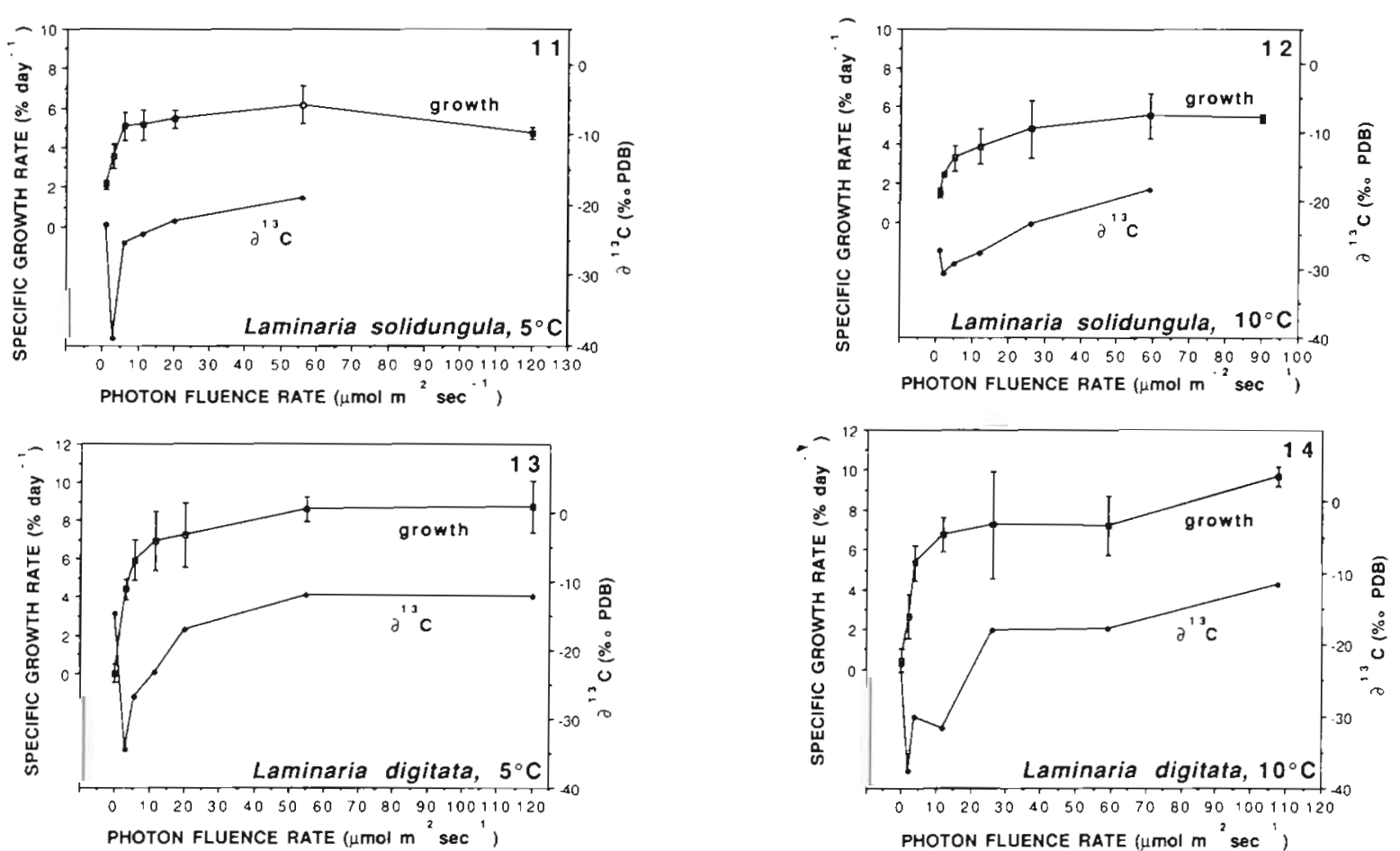

Figs 10 to 14. Growth and stable carbon isotope composition versus photon fluence rates in endemic Arctic (Figs. 10 to 12) and cold-temperate (Figs. 13 and 14) Laminaria species (18:6 h light:dark cycle) 

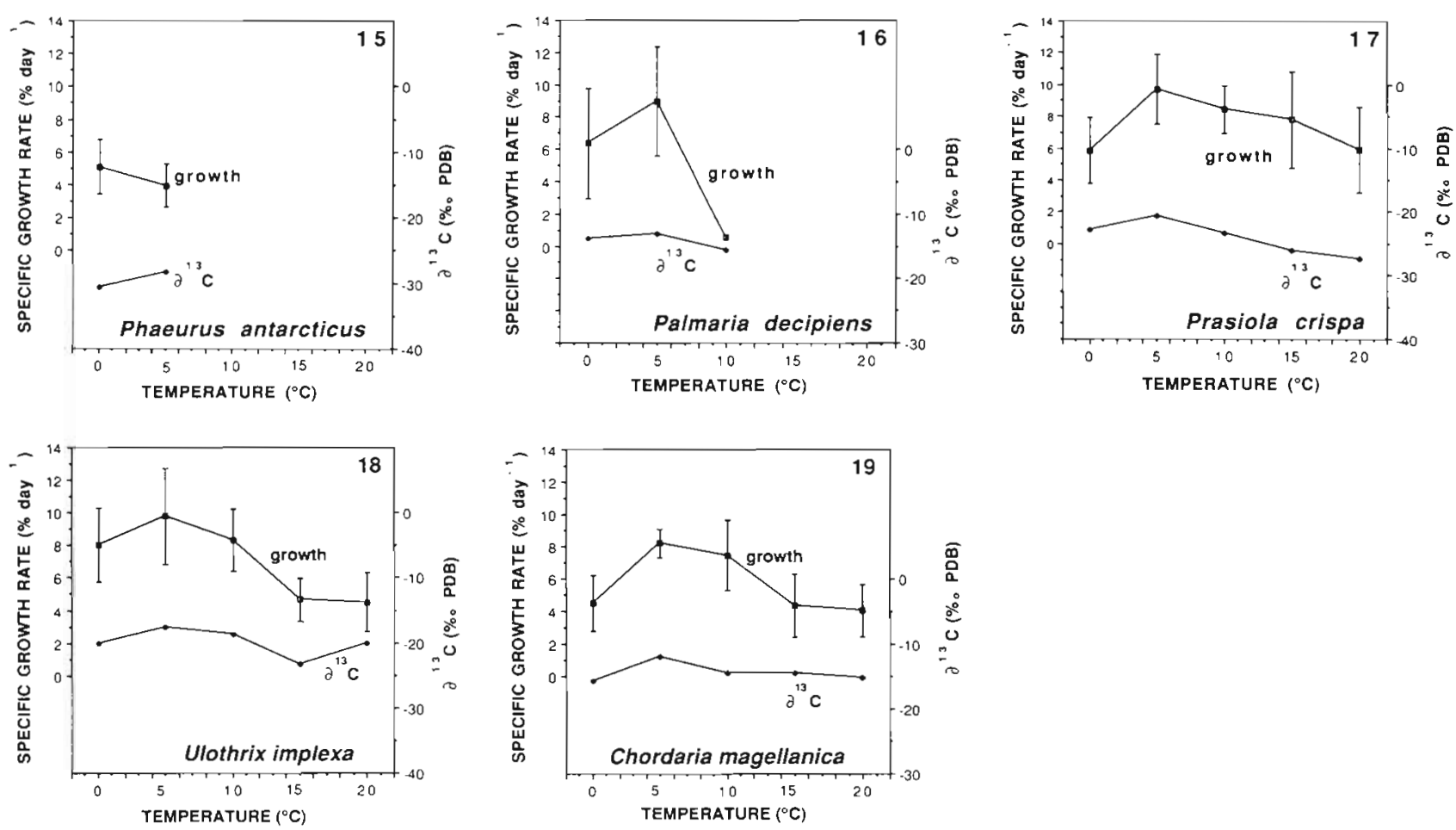

Figs. 15 to 19. Growth and stable carbon isotope composition of endemic Antarctic (Figs. 15 and 16), Antarctic cold-temperate (Figs. 17 and 18) and exclusively cold-temperate (Fig. 20) macroalgae in relation to temperature under growth-saturating light conditions $\left(50 \mu \mathrm{mol} \mathrm{m} \mathrm{m}^{-2} \mathrm{~s}^{-1}, 18: 6 \mathrm{~h}\right.$ light:dark cycle). Growth data were taken from Wiencke \& tom Dieck (1989, 1990)

(Wiencke \& tom Dieck 1989, 1990) but also to the low light conditions in their environment. They can be compared in this respect to Antarctic benthic and ice microalgae and to the deep water red alga Atractopora hypnoides in which growth becomes inhibited at $\geq 15$ to $20 \mu \mathrm{mol} \mathrm{m}{ }^{-2} \mathrm{~s}^{-1}$ (Rivkin \& Put 1987) or at $30 \mu \mathrm{mol} \mathrm{m}{ }^{-2}$ $\mathrm{s}^{-1}$ (Maggs \& Guiry 1987), respectively.

The isotope data indicate a relationship between irradiance and carbon isotope composition. In the light intensity range 4 to $50 \mu \mathrm{mol} \mathrm{m} \mathrm{m}^{-2} \mathrm{~s}^{-1}$ (LD 18:6 h) strong ${ }^{13} \mathrm{C}$ enrichments of 10 to $25 \%$ with increasing photon fluence rates were measured for Desmarestia antarctica, Himantothallus grandifolius, Laminaria solidungula and L. digitata (Figs. 1, 6, and 10 to 14), whereas D. anceps, Adenocystis utricularis and Acrosiphonia arcta were characterized by ${ }^{13} \mathrm{C}$ enrichments of only 2 to $5 \%$ (Figs. 2, 3, and 7 to 9 ). The last 2 species show a factor of 2 to 3 lower specific growth rates compared to the other algae. Under $6: 18 \mathrm{~h} \mathrm{LD}$ no continuous isotope change with increasing light intensity is found in $A$. utricularis (Fig. 7). These results are in accordance with findings of Wefer \& Killingley (1986) and Cooper (1987) who showed ${ }^{12} \mathrm{C}$ depletions with increasing light intensity in the macroalga Halimeda incrassata, and the seagrass Posidonia oceanica, respectively.

The temperature experiments show that the isotope variations are mostly relatively small (ca $2 \%$ ) in the range 0 to $20^{\circ} \mathrm{C}$ (Figs. 2, 3, and 14 to 19). As temperature affects isotopic composition of the inorganic carbon pool (Deuser \& Degens 1967, Mook et al. 1974) one could expect a continuous depletion of ${ }^{12} \mathrm{C}$ in the plants with increasing temperature. However, this is not the case. The results presented confirm findings of Degens et al. (1968a), Christeller et al. (1976), Estep et al. (1978) and O'Leary (1981) who argue against a strong direct influence of temperature on the ${ }^{13} \mathrm{C}$ discrimination $\mathrm{du}$ ring carbon fixation, a hypothesis favoured by Sackett et al. (1965) and Fontugne \& Duplessy (1981).

Higher isotope ratios generally occur with increasing specific growth rates (Figs. 16 to 19 ) at certain photon fluence rates and temperatures. Our hypothesis is that higher carbon uptake rates increase diffusion resistance under $\mathrm{CO}_{2}$-limiting conditions (see also Raven 1970, Pardue et al. 1976, Lazerte 1983). High carbon demands may cause isotopic disequilibria in the bulk medium, at the cell surfaces (see Smith \& Walker 1980) and in the protoplasm. These disequilibria can result in a preferential assimilation of heavier carbon by the organisms (Degens et al. 1968a, Deuser 1970, O'Leary 1981). If the chloroplast (or the whole cell) is treated theoretically as a closed system all carbon independent of its isotopic nature will be fixed (Estep et al. 1978). This would result in no fractionation. In an open system, ${ }^{12} \mathrm{CO}_{2}$ would be in ample supply, resulting in 
maximum isotope fractionations of about -20 to $-40 \%$. Experiments with RuBP-C (ribulose-1,5,-bisphosphate carboxylase) approach these 'open' conditions (Estep et al. 1978). In nature the carbon isotope composition of plants will be dependent on the primary $\mathrm{CO}_{2}$ availability, the carbon consumption due to assimilation and related diffusive processes.

Unbalanced concentrations of free $\mathrm{CO}_{2}$ and $\mathrm{HCO}_{3}^{-}$ generated by photosynthetic activity were measured by Brechnignac et al. (1986) for the marine macroalga Chondrus crispus in an assimilation chamber. As isotopic equilibrium is attained many times more slowly than chemical equilibrium (O'Leary 1981), isotopic disequilibria should necessarily occur in macroalgae with high carbon demands. Rapid assimilation may further reduce the $\mathrm{CO}_{2}$ level inside the cells. This is shown by Farquhar et al. (1982b) who related the $\delta^{13} \mathrm{C}$ values of plants to the ratio of intercellular and ambient partial pressures.

In our experiments photon fluence rate and carbon isotope ratios were not always related in the entire light intensity range. Laminaria solidungula, L. digitata and Desmarestia anceps showed ${ }^{12} \mathrm{C}$ enrichments at $<4 \mu \mathrm{mol} \mathrm{m}{ }^{-2} \mathrm{~s}^{-1}$ (Figs. 2, 3, and 10 to 14). At these low light intensities growth and carbon uptake rates are too small to influence the carbon isotope composition of the algae in short-term experiments. Rather, the isotope

Table 2. Stable carbon isotope composition and $\mathrm{C} / \mathrm{N}$ values of macroalgae grown in different temperatures. The experiments were done under growth-saturating light conditions $(50 \mu \mathrm{mol}$ $\mathrm{m}^{-2} \mathrm{~s}^{-\mathrm{i}}, 18: 6 \mathrm{~h}$ light:dark cycle, duration $5 \mathrm{wk}$ )

\begin{tabular}{|c|c|c|c|}
\hline Species & $\begin{array}{c}\text { Temp. } \\
\left({ }^{\circ} \mathrm{C}\right)\end{array}$ & $\begin{array}{c}\delta^{13} \mathrm{C} \\
\left(\%{ }^{\circ} \mathrm{PDB}\right)\end{array}$ & $\begin{array}{c}\mathrm{C} / \mathrm{N} \\
\text { (atom) }\end{array}$ \\
\hline Phaeurus antarcticus & $\begin{array}{l}0 \\
5\end{array}$ & $\begin{array}{l}-30.66 \\
-28.33\end{array}$ & $\begin{array}{l}12.63 \\
14.09\end{array}$ \\
\hline Palmaria decipiens & $\begin{array}{r}0 \\
5 \\
10\end{array}$ & $\begin{array}{l}-13.89 \\
-13.07 \\
-15.56\end{array}$ & $\begin{array}{r}7.31 \\
12.19 \\
9.08\end{array}$ \\
\hline Prasiola crispa & $\begin{array}{r}0 \\
5 \\
10 \\
15 \\
20\end{array}$ & $\begin{array}{l}-22.88 \\
-20.62 \\
-23.32 \\
-26.18 \\
-27.37\end{array}$ & $\begin{array}{l}9.40 \\
7.90 \\
8.97 \\
7.15 \\
6.13\end{array}$ \\
\hline Ulothrix implexa & $\begin{array}{r}0 \\
5 \\
10 \\
15 \\
20\end{array}$ & $\begin{array}{l}-20.04 \\
-17.63 \\
-18.64 \\
-23.22 \\
-20.02\end{array}$ & $\begin{array}{r}10.17 \\
10.08 \\
10.49 \\
8.74 \\
11.71\end{array}$ \\
\hline Chordaria magellanica & $\begin{array}{r}0 \\
5 \\
10 \\
15 \\
20\end{array}$ & $\begin{array}{l}-15.71 \\
-12.03 \\
-14.40 \\
-14.41 \\
-15.15\end{array}$ & $\begin{array}{r}8.29 \\
9.96 \\
10.36 \\
9.41 \\
9.00\end{array}$ \\
\hline
\end{tabular}

values mirror the pre-culture light conditions between 15 and $30 \mu \mathrm{mol} \mathrm{m} \mathrm{m}^{-2} \mathrm{~s}^{-1}$

Photon fluence rate dependent isotope changes can be very large, for example, in Laminaria digitata the isotope values increased from $-37.52 \%$ at $2 \mu \mathrm{mol} \mathrm{m} \mathrm{m}^{-2}$ $\mathrm{s}^{-1}$ to $-11.54 \%$ at $107.5 \mu \mathrm{mol} \mathrm{m} \mathrm{m}^{-2} \mathrm{~s}^{-1}$ (Fig. 14). Thus, the values are in the range of $\mathrm{C}_{3}(-32$ to $-22 \%)$ and $\mathrm{C}_{4}$ plants ( -23 to $-9 \%$; Rounick \& Winterbourn 1986). As macroalgae must be considered $C_{3}$ plants (Lobban et al. 1985), we do not recommend the use of stable carbon isotopes to differentiate between $\mathrm{C}_{3}$ and $\mathrm{C}_{4}$ plants (see also Smith \& Walker 1980).

Stimulated carbohydrate synthesis, as inferred from the elemental ratios of Desmarestia antarctica and Adenocystis utricularis (Table 1) and of Palmaria decipiens and Prasiola crispa (Table 2) may also alter the isotopic composition to some degree. However, these isotopic changes should be in the range of only a few per mil (Degens 1969). Chemical alterations cannot be responsible for the observed isotope variations of 8 and $20 \%$ for $D$. antarctica and $A$. utricularis.

In our investigations we related the carbon isotope ratios with growth, not with carbon assimilation. Growth rates may be lower compared to carbon fixation rates in cases where storage compounds or spores/gametes are formed. This may be the reason for sometimes different shapes of the growth and carbon isotope curves (Figs. 1, 2 and 6). Furthermore, it must be emphasized that we did not consider respiration processes which may also influence carbon isotope composition (O'Leary 1981). More knowledge concerning cell-internal processes with regard to carbon isotope ratios is needed for further comprehension. On the other hand, carbon isotope compositions of various plants may give important information for the understanding of biological and chemical processes inside the plants.

In support of our concept stable carbon isotope compositions of about 20 macroalgae from Antarctica show that species living in greater water depth with low growth rates have much lighter values (ca -30 to $-34 \%$ ) than faster-growing algae from shallower depths (ca $-10 \%$; Fischer \& Wiencke 1989). Hence, it should be possible to determine the depth distribution of macroalgae using $\delta^{13} \mathrm{C}$ values. The results of this study are also important for investigations where stable carbon isotopes are used as marker compounds, e.g. in studies on the organisation of food webs (Dunton \& Schell 1987, Duggins et al. 1989) and on sedimentation processes in the oceans.

Acknowledgements. A generous grant from the Deutsche Forschungsgemeinschaft is greatly acknowledged. Thanks also go to the Instituto Antarctico Chileno, Santiago de Chile and to R. Westermeier, Universidad Austral de Chile, Valdivia, for the opportunity to participate on 2 expeditions to Antarctica. Cultures of Himantothallus grandifolius as well as 
of Laminaria solidungula and $L$. digitata were gratefully obtained from M. Clayton, Melbourne and K. Lüning, Hamburg, respectively. Finally thanks go to C. Langreder, Bremerhaven, for maintaining the cultures and for preparing the figures, and to M. Segl and B. Meyer, Bremen, for measuring the carbon isotope compositions. This research was funded by the Deutsche Forschungsgemeinschaft (Sonderforschungsbereich 261 at Bremen University, Contribution 14). This is publication no. 284 of the Altred Wegener Institute of Polar and Marine Research at Bremerhaven.

\section{LITERATURE CITED}

Benedict, C. R. Wong, W. W. L., Wong, J. H. H. (1980). Fractionation of the stable isotopes of inorganic carbon by seagrasses. Pl. Physiol. 65: 512-517

Biggs, W. W., Edison, A. G., Eastin, J. D., Brown, K. W. Maranville, W. J., Clegg, M. D. (1971). Photosynthesis light sensor and meter. Ecology 52: 125-131

Bolton, J. J., Lüning, K. (1982). Optimal growth and maximal survival temperatures of Atlantic Laminaria species (Phaeophyta) in culture. Mar Biol. 66: 89-94

Brechnignac, F., Andre, M., Gerbaud, A. (1986). Preferential photosynthetic uptake of exogenous $\mathrm{HCO}_{3}^{-}$in the marine macroalgae Chondrus crispus. Pl. Physiol. 80: 1059-1062

Calder, J. A., Parker, P. L. (1973). Geochemical implications of induced changes in ${ }^{13} \mathrm{C}$ fractionation by blue-green algae. Geochim. cosmochim. Acta 37: 133-140

Chapman, A. R. O., Lindley, J. E. (1980). Seasonal growth of Laminaria solidungula in the Canadian high Arctic in relation to rradiance and dissolved nutrient concentrations. Mar. Biol. 57: 1-5

Christeller, J. T., Laing, W. A., Troughton, J. H. (1976). Isotope discrimination by Ribulose-1,5-Diphosphate Carboxylase. No effect of temperature or $\mathrm{HCO}_{3}^{-}$concentration. Pl. Physiol. 57: 580-582

Copper, L. W (1987). Stable carbon isotope in the seagrass Posidonia oceanica: evidence for variability due to light intensity. EOS Trans. Am. geophys. Un. 68: 1702

Craig, H. (1957). Isotopic standards for carbon and oxygen and correction factors for mass spectrometric analysis of carbon dioxide. Geochem. cosmochim. Acta 3: 133-149

Degens, E. T (1969). Biogeochemistry of stable carbon isotopes. In: Eglinton, G., Murphy, M. T J. (eds.) Organic Geochemistry. Springer, Berlin, p. 304-329

Degens, E. T., Guillard, R. R. L., Sackett, W M., Hellebust, J. A. (1968a). Metabolic fractionation of carbon isotopes in marine plankton - I. Temperature and respiration experiments. Deep-Sea Res. 15: 1-9

Deuser, W. G. (1970). Isotopic evidence for diminishing supply of available carbon during diatom bloom in the Black Sea. Nature, Lond. 225: 1069-1070

Deuser, W. G., Degens, E. T (1967). Carbon isotope fractionation in the system $\mathrm{CO}_{2}$ (gas)- $\mathrm{CO}_{2}$ (aqueous) $-\mathrm{HCO}_{3}^{-}$(aqueous). Nature, Lond. 215: 1033-1035

Dieck, I. tom (1989). Vergleichende Untersuchungen zur Ökophysiologie und Kreuzbarkeit innerhalb der digitaten. Sektion der Gattung Laminaria Lamouroux. Ph.D. thesis, University of Hamburg

Duggins, D. O., Simenstad, C. A., Estes, J. A. (1989). Magnification of secondary production by kelp detritus in coastal marine ecosystems. Nature, Lond. 245: 170-173

Dunton, K. H., Schell, D. M. (1987). Dependence of consumers on macroalgal (Laminaria solidungula) carbon in an arctic kelp community: $\delta^{13} \mathrm{C}$ evidence. Mar. Biol. 93: 615-625
Estep, M. F., Tabita, R. F., Parker, P. L., Van Baalen, C. (1978). Carbon isotope fractionation by Ribulose-1,5-Biphosphate Carboxylase from various organisms. Pl. Physiol. 61 $680-687$

Farquhar, G. D., O'Leary, M. H., Berry, J. A. (1982b). On the relationship between carbon isotope discrimination and the intercellular carbon dioxide concentration in leaves Aust. J. PI. Physiol. 9: 121-137

Fischer, G., Wiencke, C. (1989). Stable carbon isotopes in organic matter from benthic marine macroalgae (Antarctica): evidence of light intensity effects. J. mar biol. Ass. U.K. 69: 732

Fontugne, M., Duplessy, J.-C. (1981). Organic carbon isotopic fractionation by marine plankton in the temperature range -1 to $31^{\circ} \mathrm{C}$. Oceanol. Acta $4: 85-90$

Fortes, M. D., Lüning, K. (1980). Growth rates of North Sea macroalgae in relation to temperature, irradiance and photoperiod. Helgoländer Meeresunters. 34: 15-29

Fry, B., Sherr, E. B. (1984). $\delta^{13} \mathrm{C}$ measurements as indicators of carbon flow in marine and freshwater ecosystems. Contr mar. Sci. 27: 13-47

Hoefs, J. (1987). Stable isotope geochemistry, Springer Verlag, Berlin

Lazerte, B. D. (1983). Stable carbon isotope ratios: Implications for the source of sediment carbon and for phytoplankton carbon assimilation in Lake Memphremagog, Quebec. Can. J. Fish. Aquat. Sci. 40: 1658-1666

Lobban, C. S., Harrison, P. J., Duncan, M. J. (1985). The physiological ecology of seaweeds. Cambridge University Press, Cambridge

Lüning, K. (1981). Light. In: Lobban, C. S., Wynne, M. J. (eds.) The biology of seaweeds. Blackwell, Oxford, p. 326-355

Lüning, K. (1985). Meeresbotanik. Verbreitung, Okophysiologie und Nutzung der marinen Makroalgen. Thieme Verlag, Stuttgart

Maggs, C. A., Guiry, M. D. (1987). Environmental control of macroalgal phenology. In: Crawford, R. M. M. (ed.) Plant life in aquatic and amphibious habitats. Blackwell, Oxford, p. $359-373$

Mook, W. G., Bommerson, J. C., Staverman, W H. (1974). Carbon isotope fractionation between dissolved bicarbonate and gaseous carbon dioxide. Earth planet. Sci. Lett. 22: $169-176$

O'Leary, M. H. (1981). Carbon isotope fractionation in plants. Phytochem. 20: 553-567

Pardue, J. W., Scalan, R. S., Van Baalen, C., Parker, P. L (1976). Maximum carbon isotope fractionation in photosynthesis by blue-green algae and a green alga. Geochim. cosmochim. Acta 40: 309-312

Park, R., Epstein, S. (1960). Carbon isotope fractionation during photosynthesis. Geochim. cosmochim. Acta 21: 110-126

Rau, G. H., Takahashi, T, Des Marais, D. J. (1989). Latitudinal variations in plankton ${ }^{13} \mathrm{C}$ : implications for $\mathrm{CO}_{2}$ and for productivity in past oceans. Nature, Lond. 341: 516-518

Raven, J. A. (1970). Exogenous inorganic carbon sources in plant photosynthesis. Biol. Rev. 45: 167-221

Rivkin, R. B., Put, M. (1987). Photosynthesis and cell division by Antarctic microalgae: comparison of benthic, planktonic and ice algae. J. Phycol. 23: 223-229

Rounick, J. S., Winterbourn, M. J. (1986). Measuring ${ }^{13} \mathrm{C}$ to ${ }^{12} \mathrm{C}$ ratios can help trace carbon pathways. Bioscience 36 : $171-177$

Sackett, W. M., Eckelmann, W. R., Bender, M. L., Be, A. W. H. (1965). Temperature dependence of carbon isotope composition in marine plankton and sediments. Science 148 : 236-237

Smith, F. A., Walker, N. A. (1980). Photosynthesis by aquatic 
plants: effects of unstirred layers in relation to assimilation of $\mathrm{CO}_{2}$ and $\mathrm{HCO}_{3}^{-}$and to carbon isotopic discrimination. New Phytol. 86: 245-259

Stein, J. R. (1973). Handbook of Phycological Methods. Culture methods and growth measurements. Cambridge University Press, Cambridge

Thayer, G. W., Parker, P. L., LaCroix, M. W., Fry, B. (1978). The stable carbon isotope ratio of some components of an eelgrass, Zostera marina. Oecologia 35: 1-12

Wefer, G., Killingley, J. S. (1986). Carbon isotopes in organic matter from a benthic algae Halimeda incrassata (Bermuda): effects of light intensity. Chem. Geol. (Isotope Geoscience Section) 59: 321-326

This article was submitted to the editor
Wiencke, C. (1988). Notes on the development of some benthic marine macroalgae of King George Island, Antarctica. Ser. Cient. INACH 37: 23-47

Wiencke, C. (1990). Seasonality of brown macroalgae from Antarctica - a long-term culture study under fluctuating Antarctic daylengths. Polar Biol. (in press)

Wiencke, C., Dieck, I. tom (1989). Temperature requirements for growth and temperature tolerance of macroalgae endemic to the Antarctic region. Mar. Ecol. Prog. Ser. 54: $189-197$

Wiencke, C., Dieck, I. tom (1990). Temperature requirements for growth and survival of macroalgae from Antarctica and southern Chile. Mar. Ecol. Prog. Ser. 59: 157-170

Manuscript first received: January 11, 1990

Revised version accepted: May 31, 1990 